\title{
Managing forest harvesting to maintain old growth in boreal and sub-boreal forests ${ }^{1}$
}

\author{
by Philip J. Burton ${ }^{2}$, Daniel D. Kneeshaw ${ }^{3}$ and K. David Coates ${ }^{4}$
}

Old-growth stands can be rare in northern coniferous forests, and hence are worthy of protection and special management. We describe some quantitative guidelines for recognizing old-growth stands and options for maintaining a long-term supply of old-growth values in landscapes managed for timber production. In the SubBoreal Spruce forests of central British Columbia, attributes most indicative of old-growth status include stand age, the density of large $\left(>1.0 \mathrm{~m}^{3}\right)$ snags and downed logs, stand basal area and volume. It is suggested that partial cutting could occur in some old-growth stands, while still maintaining their structural and functional attributes, if large logs, snags and trees are retained at the threshold densities necessary to recognise old-growth status. At the landscape level, the use of extended timber crop rotations is advocated. Planning for a tapered forest age class distribution (with decreasing areas of forest allowed to persist to successively older ages) is suggested as a means of sustainably generating true old-growth, and as an alternative to the use of partial cutting and patch retention. Arithmetic formulas are developed which provide guidelines for the proportion of the forest land base to be kept in each successive age class. This model for regulating human disturbance in commercial forests holds promise as a mechanism for allowing continued timber harvest and even-aged stand management while retaining a near-natural proportion of old-growth forest in northern landscapes.

Key words: disturbance regime, even-aged management, extended rotations, forest age class structure, forest management, oldgrowth attributes, rotation length, silvicultural systems, subboreal spruce zone, timber supply planning.
Dans les forêts conifériennes nordiques les vieux peuplements sont souvent rares et méritent donc une stratégie de protection et de gestion spéciale. Nous décrivons quelques conseils quantitatifs pour reconnaître les forêts anciennes et des options pour le maintien à long-term des valeurs associées à ces peuplements dans les paysages aménagés pour la production de matière ligneuse. Les attributs le plus indicatif du stade de forêt ancienne dans la pessière sous-boréale de la Colombie Britannique incluent l'âge de peuplement, la densité de gros $\left(>1 \mathrm{~m}^{3}\right)$ chicots et de troncs à terre, la surface terrière et le volume de bois. Les attributs structuraux et fonctionaux des vieilles forêts pourraient être maintenues lors des coupes partielles si les grands troncs, chicots et arbres sont conservés au-dessus du seuil défini pour les forêts anciennes. À l'échelle du paysage, ces forêts pourraient être maintenues en utilisant les rotations forestières étendues. La planification d'une distribution décroissante de classe d'âges (la superficie de forêt dans chaque classe d'âge diminue dans le temps) est suggéré comme un moyen de produire des vieilles forêts. Cette technique est aussi une alternative aux coupes partielles et à la conservation de parcelles forestières dans les coupes à blancs. Les formules arithmétiques sont développées afin de déterminer la proportion du territoire forestier à garder dans chaque classe d'âge. Ce modèle, de planification de perturbations anthropiques dans les forêts commerciales est prometteur pour le maintien et la gestion de la récolte forestière dans les systèmes sylvicoles équiens tout en maintenant des proportions quasinaturelles de forêts anciennes dans les écosystèmes boréaux.

Mots clés : aménagement équienne, aménagement à l'echelle de la forêt, analyse de l'approvisionnement en matière ligneuse, attributs de forêts anciennes, pessière sous-boréale, plannification de paysages forestiers, régime de perturbation, revolution étendue, structure d'âge d'une forêt, systèmes sylvicoles, zone d'épinette sous-boréale

\section{Introduction}

In many forests of the world, disturbances mediated by human activities are replacing natural disturbance regimes. Human disturbances range from the intentional, local, and essentially irreversible (e.g., urban expansion) to the inadvertent and diffuse (e.g., the effects of air pollution). Intermediate in its impacts may be the periodic, clearcut harvesting of wild forests that had histor-

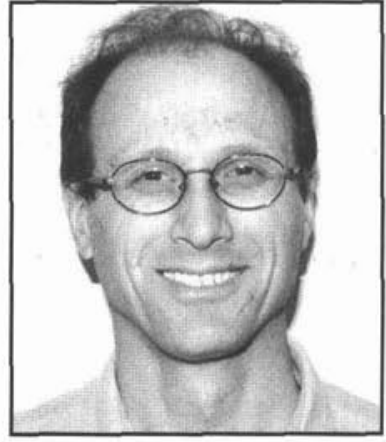

Philip Burton

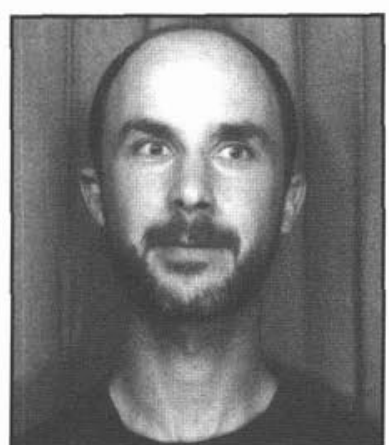

Daniel Kneeshaw

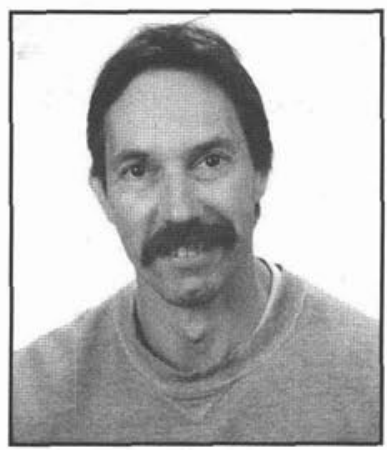

David Coates
${ }^{1}$ Presented at the Second International Workshop on Disturbance Dynamics in Boreal Forests, Rouyn-Noranda, Québec, 26-30 August 1996.

${ }^{2}$ Symbios Research and Restoration, P.O. Box 3398, Smithers, British Columbia V0J 2N0. E-mail: symbios@mail.bulkley.net

${ }^{3}$ Le Groupe de Recherche en Ecologie Forestiere, Université du Québec a Montréal, C.P. 8888, Succ. A, Montréal, Québec H3C 3P8. E-mail: c3604@er.uqam.ca ${ }^{4}$ B.C. Forest Service, Research Section, P.O. Bag 5000, Smithers, British Columbia V0J 2N0 E-mail: Dave.Coates@gems7.gov.bc.ca ically been subject to periodic, stand-replacing wildfires. Because of their adaptation to stand-destroying disturbances (Larsen 1980, Heinselman 1981, Zasada et al. 1992), many boreal and sub-boreal forests may be able to retain their health and vigour as wildfire is replaced by clearcut logging, unlike some other forests which are not usually subject to large-scale disturbances. Wildfire and clearcut logging 
and their resultant second-growth forests can differ markedly in terms of residual vegetation, structural diversity, and spatial pattern (Hammond 1991, Keenan and Kimmins 1993, DeLong and Tanner 1996, Bergeron et al. 1999), but they are similar in triggering the regeneration of even-aged stands. The commercial harvesting of boreal and sub-boreal forests may be less detrimental to overall biodiversity and ecological sustainability than is large-scale timber extraction from tropical forests, temperate rain forests, and other ecosystems not adapted to recurrent stand-replacing disturbance.

The return interval of stand-destroying wildfire tends to be very short, often less than 100 years, in much of the boreal forest (Johnson 1992, Payette 1992). Though approximately one-third of a landscape repeatedly disturbed by wildfire (with uniform susceptibility of all forest age classes) would still be older than the average fire return interval, it is estimated that only $5 \%$ to $10 \%$ of boreal landscapes would usually consist of stands older than 200 years (Johnson et al. 1995). Timber management rotations of 70 to 120 years further prevent most boreal stands from achieving old-growth status.

We here address methods for conserving old-growth values in a sub-boreal region of central British Columbia (B.C.), taking our cues from nature at both stand and landscape levels. These approaches can be added to the growing toolbox of techniques designed to maintain the character and integrity of managed forests in northern Canada (Burton et al. 1992, Coates and Steventon 1995, Galindo-Leal and Bunnell 1995, Gauthier et al. 1996, Lieffers et al. 1996, Bergeron and Harvey 1997, Coates 1997, Bergeron et al. 1999), and should be applicable elsewhere too.

The term "old-growth forest" is often used in a vague and emotionally charged manner. Yet the identification of old-growth forest and the development of management strategies to protect and sustain old-growth values are goals of many forest management agencies. Forest ecologists recognise old-growth forest as the final phase of natural stand development, defined by the population dynamics of the tree layer (Oliver and Larson 1990, Hayward 1991, Wells et al. 1998). Old-growth forest is dominated by single-tree replacement processes (gap dynamics) rather than those of stand-level replacement (e.g., by wildfire or clear-cut logging). However, attention is more often paid to the structural features that are a consequence of this functional distinction. Characteristic structural attributes of old stands include large, old trees, some of which are dying (leaving snags and creating canopy gaps) and falling (becoming logs). In addition, there are many young trees of all ages and sizes, which contribute to a multi-layered canopy and complex spatial pattern (Franklin et al. 1981, Moir 1992). There may or may not be a shift in species composition during the development of old-growth forest. Critical values for distinguishing old-growth status on the basis of tree size, age, or snag and log densities clearly differ among forest types (Mehl 1992, Pojar et al. 1992). The importance of each diagnostic attribute can also vary with site and with management objectives, especially the balance to be achieved between conservation and production goals. It is desirable to have a consistent, quantitative method for the recognition of old-growth stands across all forest types (e.g., Kneeshaw and Burton 1998), even though local calibration will always be needed.

The prevalence of wildfire in northern landscapes means that few wild stands persist long enough to develop into true old growth. Likewise, extensive insect outbreaks (by spruce budworm, bark beetles, and tent caterpillars) are common standlevel disturbances. As forests are brought under management, industrial timber rotations ( 80 to 120 years in B.C.) also preclude the development of old-growth stands (Fig. 1). These disturbance regimes contribute to the rarity of old-growth stands in boreal and sub-boreal landscapes, and this rarity makes them especially valuable for biodiversity conservation and ecosystem research. Landscape-based definitions of old-growth forest may be more appropriate in boreal and sub-boreal regions (Barnes 1989, Johnson et al. 1995). For example, all stands older than the median disturbance return interval (as defined for a landscape or region) can be considered old growth (Achuff 1989, Hunter 1989). Old-growth definitions and indices are reviewed elsewhere (e.g., Kaufmann et al. 1992, Kneeshaw and Burton 1998, Wells et al. 1998), and justifications for the conservation of old-growth stands and old-growth values are widespread in the literature (e.g., Whitney 1987, Kaufmann et al. 1992).

Pressures for the liquidation of old-growth forests come primarily from industrial forestry. Older stands are given a priority for harvest because they often have the highest standing crops of commercial fibre, are perceived to be at greater risk of deterioration through root rot or insect infestation, and they occupy land which could be supporting more efficient fibre production in young, second-growth stands (Teeguarden 1982, Robinson 1988). If old-growth forests are to be found outside of parks and reserves in the future, there is a need for various techniques which constrain the logging of old-growth forests, in a manner that would sustain some old-growth stands, old-growth attributes, and old-growth processes into the indefinite future. This concept of "old-growth management" presumes that old growth is not equivalent to virgin, primeval forest, never disturbed by humans. Rather, it is based on the premise that old growth is a renewable resource that can eventually develop after different kinds of disturbance (including human exploitation).

This paper explores forest management options for the conservation of old growth at stand and landscape levels in areas designated for industrial forest management. We first briefly describe a scoring system developed by Kneeshaw and Burton (1998) that identifies the structural characteristics of oldgrowth forest Sub-Boreal Spruce stands in the north-central interior of British Columbia, and argue that these attributes should be retained in order to maintain old-growth characteristics after partial cutting. We then suggest landscape-level alternatives for the maintenance of old-growth forest, particularly through the strategic use of extended rotations. These landscape management guidelines are applicable to all forests dominated by stand-replacing wildfires and even-aged timber management.

\section{Managing Old Growth at the Stand Level}

It has been widely suggested that forest stands could be managed for old-growth attributes while still harvesting some timber (Newton and Cole 1987, Hansen et al. 1991, McComb et al. 1993, Perry 1994). Hagar et al. (1996) found that commercial thinning of 40- to 55-year-old Douglas fir (Pseudotsuga menziesii (Mirb.) Franco) stands in Oregon, U.S.A., effectively increased the abundance of several bird species normally associated with old, unmanaged forests. Likewise, Singer and Lorimer (1997) used crown release in sugar maple (Acer 
saccharum Marsh.) stands in northern Wisconsin, U.S.A., to accelerate the development of old-growth attributes. Kneeshaw and Burton (1997) suggest that the creation of canopy gaps in Sub-Boreal Spruce stands could accelerate the attainment of old-growth status in mature stands, similar to the impact of bark beetles and to pockets of root rot. Runkle (1991) and Coates and Burton (1997) advocate the mimicry of gap dynamics in designing silvicultural systems for ecosystem management objectives. But how much disturbance can be accommodated, and how much timber can be removed, without compromising the old-growth values one seeks to protect?

To answer this question requires a knowledge of stand development processes and their associated structural and compositional changes. In order to understand these dynamics in a particular forest type, Kneeshaw and Burton (1997) reconstructed the stand development patterns of several mature and old-growth stands in the moist cold subzone of the SubBoreal Spruce biogeoclimatic zone (SBSmc) of central B.C. ( $53^{\circ}$ to $55^{\circ} \mathrm{N}$ lat., $124^{\circ}$ to $128^{\circ} \mathrm{W}$ long.). Stands were dominated by hybrids of white spruce (Picea glauca (Moench) Voss) and Engelmann spruce ( $P$. engelmannii Parry), and had a large component of subalpine fir (Abies lasiocarpa (Hook.) Nutt.) with some lodgepole pine (Pinus contorta Dougl.) and trembling aspen (Populus tremuloides Michx.). Characterised by long, cold winters and moist cool summers, this region of interior plateaux can be considered intermediate between true boreal forest (located further north and east) and subalpine sprucefir forest found above $1100 \mathrm{~m}$ to $1300 \mathrm{~m}$ elevation in this area (Meidinger et al. 1991). Analysis of tree population structures revealed that these stands had individualistic development histories, but were generally characterised by long periods of establishment, decreasing amounts of Populus and Pinus over time, increasing amounts of Abies over time, and the persistence of Picea in some old stands but not in others (Kneeshaw and Burton 1997). Descriptions of the population structures of these stands were subsequently correlated with a number of structural attributes to devise old-growth rating schemes (Burton and Coates 1996, Kneeshaw and Burton 1998). Development of these old-growth scores was based on the recognition of a minimal set of stand attributes which denote the transition to full old-growth status in these forests (Kneeshaw and Burton 1998): stands should be at least 184 years old (assigned a weight of $37 \%$ ); have at least $50 \mathrm{big}$ (>1 $\mathrm{m}^{3}$ per piece) downed logs per ha ( $23 \%$ weight); have at least $57 \mathrm{~m}^{2} /$ ha live tree basal area ( $15 \%$ weight); have at least $531 \mathrm{~m}^{3} /$ ha total live stem volume (13\% weight); and have at least 22 big $\left(>1 \mathrm{~m}^{3}\right)$ snags per ha (12\% weight). Though these attributes are purely structural or mensurational, their correlation with dominance by the trees previously in the understory makes them good indicators of gap dynamics and other old-growth processes. Stands with these attributes will usually have attained the combination of dense shade, thick forest floor, and canopy gaps that sustain numerous species of plants and animals associated with undisturbed primary forests. Because of their association with functional traits, it can be expected that these levels of these features are necessary to maintain the diversity, resilience, and productivity of old-growth sub-boreal stands.

Whether these levels of these features are sufficient for the maintenance of old-growth functionality remains to be tested experimentally. We suggest that stands (especially those greater than 184 years old) could be partially cut and would still maintain old-growth character so long as these threshold levels are maintained. These criteria would allow some timber extraction (up to $148 \mathrm{~m}^{3} / \mathrm{ha}$, net merchantable volume) in approximately half of the old-growth stands we inspected. Other developmentally younger stands could be advanced to structurally resemble older stands through manipulations such as the removal of early successional trees to release fir and spruce. These trees would then more quickly attain the larger sizes characteristic of old-growth forests of this region. Harvesting could be conducted as part of a single-tree or group selection system designed around an uneven-aged management model, as practised elsewhere in spruce-fir forests (Alexander and Edminster 1977). Because of their importance to many forms of wildlife (Hunter 1990, Hansen et al. 1991), the retention of snags and logs, especially the large ones $\left(>1.0 \mathrm{~m}^{3}\right.$ per piece, which corresponds to $25 \mathrm{~m}$ tall trees having $\mathrm{dbh}>$ $35 \mathrm{~cm}$ ) is particularly important. Consistent with the tenets of ecosystem management (Galindo-Leal and Bunnell 1995, Christensen et al. 1996), resource extraction can proceed in a stand to be managed for old-growth features only if there is merchantable wood in excess of these thresholds, and if it can be extracted without damaging the residual stand and its soils. In almost half of the old-growth stands sampled by Kneeshaw and Burton $(1997,1998)$, basal area removals of approximately $6 \mathrm{~m}^{2} /$ ha every 20 years are likely to be ecologically and silviculturally sustainable without compromising many old-growth values (Burton and Coates 1996).

Alternatives to clear-cut silviculture are suggested by the ability of SBSmc forest to maintain itself in the absence of standlevel disturbance. Subalpine fir is prolific at producing seedlings, but a high proportion of spruce seedlings are apparently recruited into the canopy too (Kneeshaw and Burton 1997), indicating that both species could be successfully managed using partial cutting methods. Subalpine fir was the only species to consistently exhibit an all-aged population structure required for formal uneven-aged management. Such stand-level oldgrowth management prescriptions might be suitable for special management areas (in which conversion of stands to uneven-aged management or old-growth status is desired, or for which specialised wildlife habitat, biodiversity conservation, watershed protection, or aesthetic objectives take priority over timber production), and small woodlots or private land holdings where some reduced intensity of timber harvest is desired.

\section{Managing Old Growth at the Landscape Level Old-Growth Rarity and Natural Disturbance Regimes}

The ubiquitous history of wildfire in boreal and sub-boreal forests, the potential impact of a permanent road network on soils and biodiversity, and the operational constraints (regarding worker safety, residual tree damage, road density and costs) to implementing partial cutting prescriptions all suggest that landscape-level old-growth management options should be explored, too. A standard approach is simply to exclude some old-growth stands from the operable forest land base. The amount of land to set aside in this manner depends on various conservation and wilderness management objectives, but also depends on the local rarity of old-growth forest. Within the Sub-Boreal Spruce zone of B.C. (about 10 million hectares) there is wide variability in the extent of remaining old growth (which for these purposes we define simply on the basis of stand 


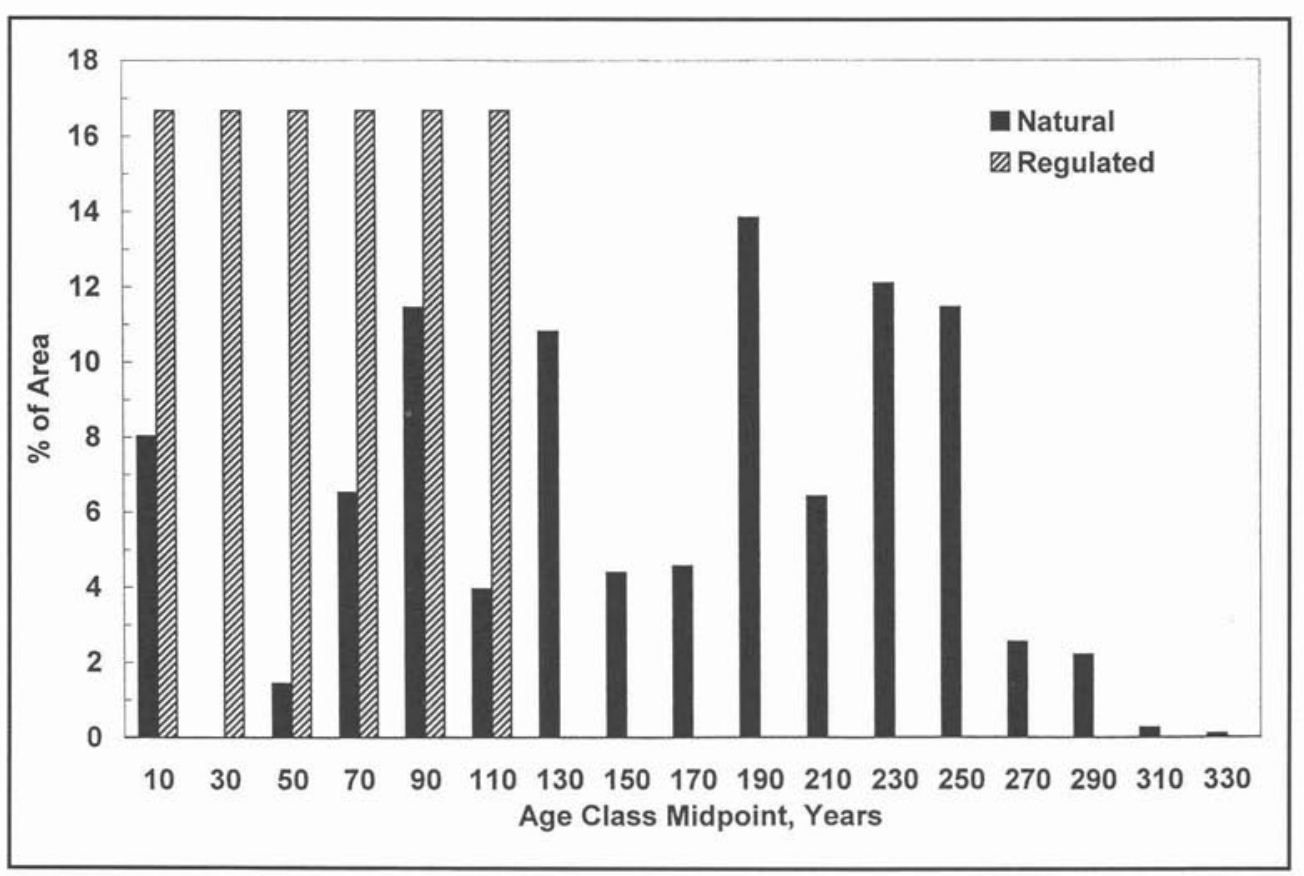

Fig. 1. The current, natural age class distribution (solid bars) of 28 714 ha of SBSmc forest west of Whitesail Reach (Ootsa Lake, B.C.; unpublished data provided courtesy of D. Steventon), as compared to the age structure for a fully regulated forest with uniform 120 year rotations (crosshatched bars).

age), depending on the local fire cycle and recent logging history. Available inventory data (J.D. Steventon, unpublished data) suggest that up to $47 \%$ of some SBSmc landscapes may be characterised by stands $>180$ years old (Fig. 1), while only $14 \%$ of a drier and warmer SBSdk landscape is $>180$ years old. In the intermediate SBSmk subzone, only $2.5 \%$ of the landscape is currently $>180$ years, due to several decades of industrial logging (Andison 1996). Where old-growth stands are rare, they are particularly worthy of protection or maintenance. However, the fate of old stands deferred from cutting is not easily predicted. We suspect that most old growth in the Sub-Boreal Spruce zone will eventually be renewed by wildfire, bark beetles, root rot, or windthrow, while a very small proportion (particularly those stands on moist ground or on northeast-facing slopes) may be maintained indefinitely in the absence of human disturbance. Protection of old-growth stands can, therefore, be only part of a strategy to maintain oldgrowth forest in the landscape.

An alternative to protection of old growth is to plan for its restoration and regeneration as part of a management plan designed to retain a component of old growth in a forested landscape. Natural, or unmanaged, landscapes appear to differ in their stand and age structures, and few exhibit the structure expected of a region in equilibrium with a constant wildfire regime (Johnson et al. 1995, Cumming et al. 1996). The theoretical equilibrium age structure for a landscape is typically described by a negative exponential or Weibull survivorship distribution (Johnson and Van Wagner 1985), characterised by large areas of young stands and progressively less area in stands of successively greater age. A landscape in equilibrium would have $37 \%$ of its area consisting of stands older than the fire cycle (Johnson and Van Wagner 1985). In this model, the distribution of stand ages results from disturbance events that affect young and old stands with equal probability (so that some young stands re-burn before some older stands are burned a first time). This is an inappropriate model for even-aged timber management where managers would like to fully protect all stands from dis- turbance until they acquire a minimal operable age. We think a two-phase (age-dependent) disturbance susceptibility model can be used as the basis for assuring the continued generation of old growth.

Depending on old-growth management goals, some stands can then be managed on longer rotations. But rather than simply applying two rotation lengths across the landscape, we suggest that successively fewer stands should be managed to older ages, thereby approximating the tapered age class distribution found in most wild forests (e.g., the oldest six age classes of the natural forest portrayed in Fig. 1). Older stands in many forest types continue to accrue wood volume and value, so longer rotation lengths can be lucrative from a timber perspective too (Franklin et al. 1981, Curtis and Marshall 1993). For example, the greatest live stem volume in SBSmc spruce stands was found in those greater than 200 years of age (Kneeshaw and Burton 1997).

\section{Designing a Forest Landscape Structure with Extended Rotations}

Let us derive some quantitative guidelines of how much forest to manage to what ages, in order to sustainably produce both timber and old-growth. "Rotation lengths" for individual stands will be assigned, in practice, through the scheduling of existing wild stands for harvest, as well as in silvicultural prescriptions for managing the second-growth stands established after disturbance. Under a regime of even-aged management in a fully regulated forest (Teeguarden 1982), the continued generation of old growth is most simply accomplished by extending rotations to include an old-growth stage prior to harvest. The necessary rotation length can be calculated from the equation

$$
\mathrm{R}=\mathrm{L} /(1-\mathrm{p})
$$

where $\mathrm{R}$ is the rotation length, $\mathrm{L}$ is the length of time required to return to old-growth status, and $p$ is the proportion of oldgrowth forest desired for a landscape (Perry 1994). For exam- 


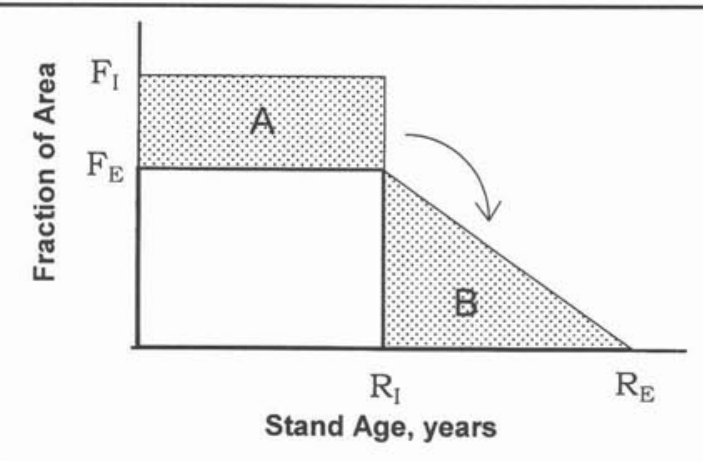

Fig. 2. Schematic representation of the reallocation of some forest land area from industrial uniform rotations (Area $\mathrm{A}$ ) to variable extended rotations (Area B). Area B must equal Area A, as expressed in Equation 3 of the text. $R_{I}=$ standard industrial rotation length; $R_{E}=\max -$ imum rotation length under extended rotations; $F_{I}=$ fraction of the land base in each age class under standard industrial rotations; and $\mathrm{F}_{\mathrm{E}}=$ fraction of the land base in each age class $<\mathrm{R}_{\mathrm{I}}$ under variable length rotations.

ple, if it takes 184 years to achieve old-growth status, and if $12 \%$ of a managed forest is desired as old growth, then $\mathrm{R}=$ $184 /(1-0.12)=209$ years as a recommended (uniform) rotation length. The proportion of a regulated forest land base in any one age class (typically 10 or 20 years) is simply

$$
F=W / R
$$

where $\mathrm{F}=$ the fraction $(0$ to 1$)$ of the landscape in a given age class; $\mathrm{W}=$ the width of age classes (years); and $\mathrm{R}=$ rotation length (years) where $\mathrm{R}$ is an even multiple of W. Under a 120year rotation, this would be $10 / 120=0.0833(8.33 \%)$ in each 10 -year age class. If there is area-based regulation of the annual cut, this means that $8.33 \% / 10$ years $=0.833 \%$ of the land base could be sustainably harvested every year (assuming perfect protection from other disturbances, access to all stands and full regeneration success after logging). With a 180 year rotation, there could only be $10 / 180=0.0556(5.56 \%)$ in each age class, or $0.556 \%$ of the land base harvested per year, a onethird reduction. This numerical example illustrates how any increase in rotation length results in a proportional decrease in the area in each age class and hence in the amount which can be sustainably harvested each year.

The universal application of long rotations across the forest land base, however, could cause some problems for those charged with managing for fibre production: forests would have to be protected long after fires and insects are likely to attack them, most crop trees would be accruing volume at sub-optimal rates, and annual harvest levels would have to be reduced in proportion to the degree that rotations are extended. While 209-year old stands are not unusual in the SBSmc, most foresters would prefer to not manage all stands on such long rotations. An alternative is to use extended rotations for only some stands, with rotation lengths varying over a range from industrial standards (about 100 years) to the age of the oldest natural stands found on the landscape (more than 300 years).

To implement such a policy, we suggest the use of "tapered age profiles" with ever-decreasing amounts of land occupied by successively older stands, as found in unmanaged land- scapes. Let us assume that the normal industrial rotation length, $\mathrm{R}_{\mathrm{I}}$, remains the same, but that the life span of some stands will be extended to $R_{E}$ years (Fig. 2). Then, the degree to which these rotations are extended will decrease uniform age class proportions (for those ages $<\mathrm{R}_{\mathrm{I}}$ ) from $\mathrm{F}_{\mathrm{I}}$ (those of a standard regulated forest) to $F_{E}$ (Fig. 2). The total graphical area of the age class distribution so reduced describes a rectangle (Area A in Fig. 2), and can be defined as $\mathrm{R}_{\mathrm{I}}\left(\mathrm{F}_{\mathrm{I}}-\mathrm{F}_{\mathrm{E}}\right)$. The total amount of forest land designated for extended rotations must then equal the amount taken out of standard regulation, and would describe a triangular age class structure (Area B in Fig. 2) having an area of $\mathrm{F}_{\mathrm{E}}\left(\mathrm{R}_{\mathrm{E}}-\mathrm{R}_{\mathrm{I}}\right) / 2$. Expressed arithmetically, since total forest area must be conserved:

$$
R_{I}\left(F_{I}-F_{E}\right)=F_{E}\left(R_{E}-R_{I}\right) / 2
$$

Ideally, if $R_{I}$ is made equal to the natural fire cycle for the region, then Area B (Fig. 2) could be set to $37 \%$ of the landscape (i.e., $\left.F_{E}\left(R_{E}-R_{I}\right) / 2=0.37\right)$ as a means of protecting a forest structure in equilibrium (as per the parameters of the Johnson and Van Wagner 1985 model). More generally, if the maximum area per age class under extended rotations $\left(\mathrm{F}_{\mathrm{E}}\right)$ or the amount each age class can be reduced by extended rotations $\left(\mathrm{F}_{\mathrm{I}}-\mathrm{F}_{\mathrm{E}}\right)$ is specified, then $\mathrm{R}_{\mathrm{I}}, \mathrm{F}_{\mathrm{I}}$ and $\mathrm{F}_{\mathrm{E}}$ are known and we can solve Equation 3 for $\mathrm{R}_{\mathrm{E}}$ by rearrangement:

$$
R_{E}=2 R_{I} F_{I} / F_{E}-R_{I}
$$

Alternatively, if $\mathrm{R}_{\mathrm{I}}$ and $\mathrm{F}_{\mathrm{I}}$ remain fixed, and if the desired length of the longest rotation, $\mathrm{R}_{\mathrm{E}}$, is specified (e.g., as the characteristic oldest age for a landscape, as derived by Johnson et al. 1995), then $R_{I}, F_{I}$ and $R_{E}$ are known and we can similarly solve Equation 3 for $\mathrm{F}_{\mathrm{E}}$ by rearrangement:

$$
F_{E}=2 R_{I} F_{I} /\left(R_{I}+R_{E}\right)
$$

Substituting Equation 2 for $\mathrm{F}_{\mathrm{I}}$, we can further simplify Equation 5 to:

$$
\mathrm{F}_{\mathrm{E}}=2 \mathrm{~W} /\left(\mathrm{R}_{\mathrm{I}}+\mathrm{R}_{\mathrm{E}}\right)
$$

With $F_{E}$ and $R_{E}$ known, we can calculate the amount of forest land to be allocated to each extended age class, using the geometry of a negatively sloped straight line, $y=b-m x$. Making $\mathrm{F}$ (the proportion of forest land in each W-year age class) the dependent variable, and stand age the independent variable, then the $y$-intercept is $\mathrm{F}_{\mathrm{E}}$ and the slope to this line is $\mathrm{F}_{\mathrm{E}}$ $/\left(R_{E}-R_{I}\right)$. For this sloping portion of the age class structure, the independent variable is the number of years past the standard industrial rotation length $\left(\mathrm{Q}-\mathrm{R}_{\mathrm{I}}-\mathrm{W} / 2\right)$, adjusted to specify the midpoint of each age class, where $\mathrm{Q}=$ any given stand age (years) $>R_{1}$. Substituting these variables into the equation for a straight line, the proportion of the land base to be allocated to each age class greater than $R_{I}$ can thus be expressed as:

$$
\mathrm{F}=\mathrm{F}_{\mathrm{E}}-\left(\mathrm{F}_{\mathrm{E}} /\left(\mathrm{R}_{\mathrm{E}}-\mathrm{R}_{\mathrm{I}}\right)\right)\left(\mathrm{Q}-\mathrm{R}_{\mathrm{I}}-\mathrm{W} / 2\right)
$$

Summarising and rearranging, we present the general step function used to generate the tapered age profile shown in Fig. 3: 


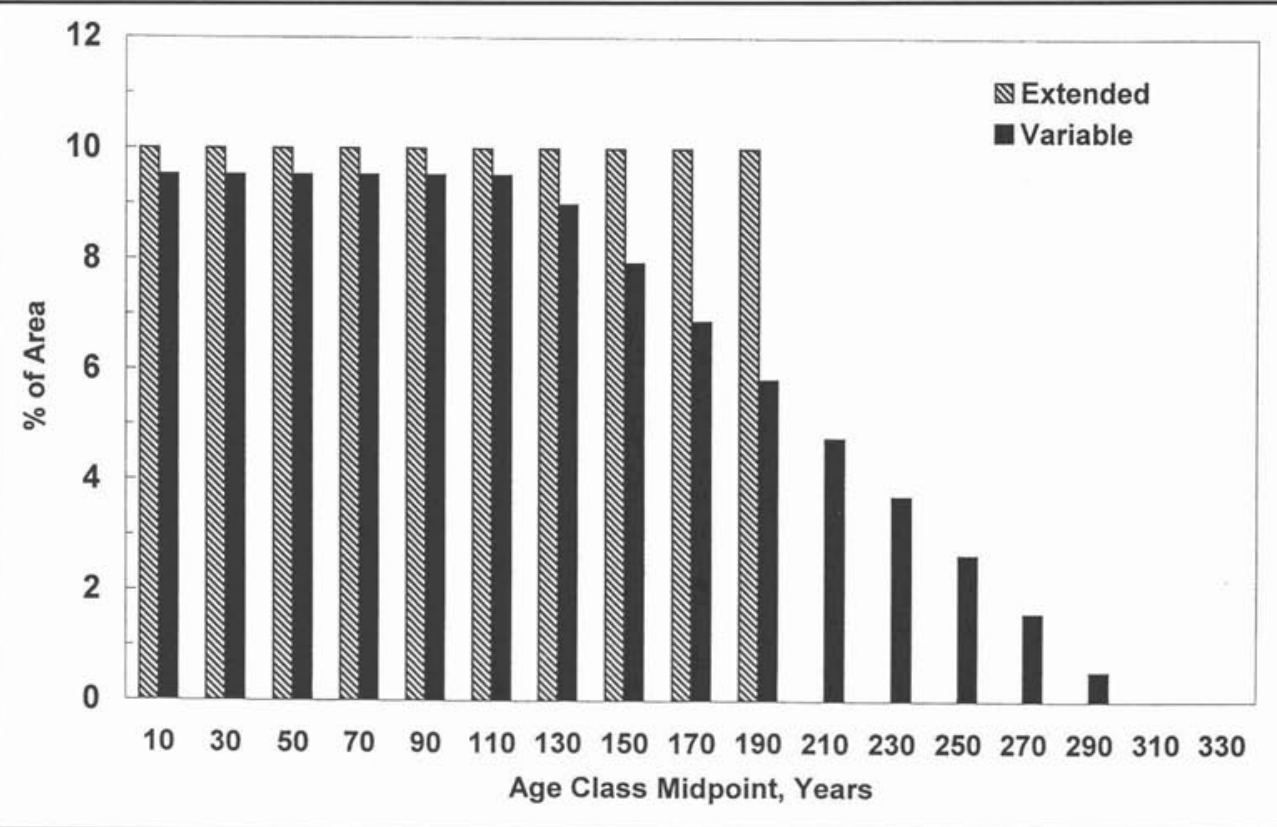

Fig. 3. Alternative age class distributions for landscape-level old-growth management: a fully regulated forest with all rotations extending to 200 years (cross-hatched bars), or variable rotations extending from 120 to 300 years (solid bars), modelled on Fig. 2 and devised using the step function given as Expression 8 in the text.

$$
F=\left\{\begin{array}{l}
F_{E} \text { if } Q \leq R_{I}, \\
F_{E}-\frac{F_{E}\left(Q-R_{I}-W / 2\right) \text { if } Q}{\left(R_{E}-R_{I}\right)}>R_{I}
\end{array}\right.
$$

where $\mathrm{F}=$ the fraction ( 0 to 1 ) of the landscape in a given age class, $\mathrm{F}_{\mathrm{E}}=$ the fraction ( 0 to 1$)$ of the landscape in age classes less than $R_{I}$ under extended rotation management, as defined in Equation 5, Q = the upper end of an age class (years), $\mathrm{R}_{\mathrm{I}}=$ standard rotation length (years), $\mathrm{W}=$ the width of age classes (years), and $R_{E}$ is the maximum age (years) of extended rotations. At the landscape level, this formula results in standard rotations for some stands, with a uniformly decreasing number of stands managed for successively greater ages. As formulated, this design generates an age profile which tapers linearly to the maximum age specified, $\mathrm{R}_{\mathrm{E}}$. Alternative formulations could prescribe curvilinear or stepwise rectangular age structures, such as the "three-cohort model" proposed by Bergeron et al. (1999) for maintaining structural and compositional diversity across the landscape.

Not all stands in the forest mosaic should be considered equally suitable as candidates for management under longer rotations. Scientists recognise that a landscape subject to frequent standinitiating events (wildfires) can support a larger area in early seral stages (without compromising its ecological integrity or the biodiversity on which it depends) than a landscape subject to rare stand-initiating events (Anonymous 1995, Lertzman et al. 1997, Bergeron et al. 1999). Similarly, the "ASIO" model of disturbance frequency (which classifies sites within a landscape as being subject to wildfires "almost never," "seldom," "infrequently," or "often," respectively) is now being used to guide naturalistic forest management in Scandinavia (Rülcker et al. 1994, Angelstam 1998). This model suggests that longer rotations are appropriate for "a" and "s" class forest stands which characterise wetter, cooler, and other fire-resistant site types. Yet, even rotations of two or three centuries may be insufficient to recreate the floristic, structural and functional traits of ancient forest stands of the "a" class, which practically need full protection in order to be conserved. Extended rotations are, therefore, suitable for " $s$ " class stands and perhaps even those "i" class stands in which one desires to maintain or restore natural variability in the disturbance interval.

Plans for forest regulation are generally based on the false assumption that all stands can be protected from injurious agents until harvested for human use. Human plans for sustainable timber harvest are, in reality, overlaid on the existing milieu of interacting natural disturbances, and may even accentuate the frequency, intensity or size of those disturbances. As a result, even the first part of the tapered age class profile portrayed in Fig. 3 is likely to have a slight negative slope (reflecting cumulative losses to natural disturbances), and the second part may be sloped concavely rather than linearly. As a precautionary measure, it would be appropriate to decrease harvest plans for each operable age class by an amount equal to its probable losses to wildfire or other agents. A factor representing incomplete forest protection from such losses could be incorporated into Expression 8.

\section{Discussion}

The mimicry of natural disturbance processes has recently become popular as an alternative to the "agricultural" model of forest timber management, with the hope that, in combination with a protected areas strategy, it will better conserve biodiversity and ecosystem integrity (Hansen et al. 1991; Runkle 1991; Swanson and Franklin 1992; Hunter 1993; Bradshaw et al. 1994; Galindo-Leal and Bunnell 1995; Gauthier et al. 1996; Lieffers et al. 1996; Angelstam 1996, 1998; Bergeron and Harvey 1997; Coates and Burton 1997; Fries et al. 1997; Bergeron et al. 1999). The need to protect some oldgrowth forest has become widely accepted. Regional rarity of old growth must play a role in determining the priority for protection and restoration of old growth: if little old growth exists (whether because of natural rarity or a history of exploitation), then most old-growth stands should be protected, 
and the generation of additional old growth should be a priority. We also maintain that it is important to manage for oldgrowth stand conditions in the industrial forest land base. Little attention has been paid to generalised procedures for how to integrate old-growth management with timber production at a strategic planning level.

Two basic old-growth management strategies can be applied outside protected areas. First, at the stand level, threshold densities of structural features (large trees, snags, logs, etc.) identified as critical to the recognition of old-growth forest can be used as criteria for the retention of core old-growth attributes under partial cutting. Some of these structural legacies can also be retained under a modified clearcut system, in which clusters of green trees (in multiple canopy layers), snags and logs are retained in large patches, rather than dispersed uniformly throughout the stand. Clark (1994) found that $28 \%$ of the stands he sampled in the SBSmc had trees that survived stand-initiating wildfires. The patch retention system (described by Coates and Steventon 1995) effectively mimics the patchy nature of wildfire (Eberhart and Woodward 1987, DeLong and Tanner 1996), and can conserve some oldgrowth habitat attributes (though rarely at old-growth densities) which are important to biodiversity (Hansen et al. 1991). Under variable retention harvest systems, the type, density, and dispersion of retained stand features can be varied along a continuum to meet particular management objectives (Franklin et al. 1997).

Second, at the landscape level, extended-rotation management can ensure that some commercial forest stands will persist to old-growth stages (Curtis 1997, Franklin et al. 1997). It can also be used to permit natural successional dynamics and seral diversity to occur. Stages that might have been eliminated or reduced (e.g., shrubs and broad-leafed trees controlled with herbicides) may now be more acceptable to forest managers if all stands do not have to meet standard industrial rotation lengths. The modification of forest management plans to include a linearly tapered age class structure is a simple solution which incorporates some aspects of disturbance theory and the empirical age class structure of wild landscapes. The arithmetic relationships presented here are certainly not required to mimic natural forest age class structures (which are incredibly variable), but are needed for timber supply planning and the determination of sustainable levels of timber harvest.

We need not assert that more old-growth forest or more naturalistic landscapes are always "better" for humankind (Rolston 1979), though there is strong evidence that some old forest is necessary for the functional integrity of forested biomes (Whitney 1987, Thomas et al. 1988, Hunter 1990). Rather, we offer a systematic approach for meeting any specified goals for representation of old growth, which should be used in conjunction with old-growth protection strategies. Neither partial cutting nor extended rotations can meet all old-growth habitat needs, such as the environmental continuity apparently required by some epiphytic lichens (Goward 1994).

Harris (1984) and Vora (1994) have called for the designation and restoration of stands to be "potential old growth" in parts of the world where most old forest stands have been logged. The protection and planned renewal of old growth clearly needs to be integrated into strategic forest management planning as soon as possible in order to prevent broad gaps in forest age class distributions and bottlenecks of critical habitat. Conservation of old growth using alternatives to the regulated forest, although requiring adjustments to current rates of timber harvesting, is currently viable because some mature and oldgrowth stands still remain in most unmanaged northern forests. Management plans, such as those that we are proposing, should be developed before options are limited by a lack of stands beyond standard industrial rotation age.

\section{Acknowledgements}

The collection of old-growth spruce stand data and development of some of the ideas reported here was supported by contracts from the Research Branch (Victoria) and the Prince Rupert Forest Region (Smithers) of the B.C. Ministry of Forests. J.D. Steventon compiled examples of forest age class structures. We appreciate the constructive comments made on the manuscript by G.L. Baskerville and C.M. Burton.

\section{References}

Achuff, P.L. 1989. Old-growth forest of the Canadian Rocky Mountain national parks. Nat. Areas J. 9: 12-26.

Alexander, R.R. and C.B. Edminster. 1977. Uneven-aged management of old growth spruce-fir forests: cutting methods and stand structure goals for the initial entry. Res. Pap. RM-186, USDA For. Serv., Fort Collins, Colorado.

Andison, D.W. 1996. Managing for landscape patterns in the subboreal forests of British Columbia. Ph.D. Thesis, Univ. of British Columbia, Vancouver, B.C.

Angelstam, P.K. 1996. Ghost of forest past - natural disturbance regimes as a basis for reconstruction of biologically diverse forests in Europe. In R. DeGraaf and R.I. Miller (eds.). Conservation of faunal diversity in forested landscapes. pp. 287-337. Chapman and Hall, London.

Angelstam, P.K. 1998. Maintaining and restoring biodiversity in European boreal forests by developing natural disturbance regimes. J. Veg. Sci. 9: 593-602.

Anonymous. 1995. Biodiversity guidebook. Forest Practices Code of British Columbia. B.C. Min. For. and B.C. Environ. Victoria, B.C. 99 p.

Barnes, B.V. 1989. Old-growth forests of the northern lake states: a landscape perspective. Nat. Areas J. 9: 45-57.

Bergeron, Y. and B. Harvey. 1997. Basing silviculture on natural ecosystem dynamics: an approach applied to the southern boreal mixedwood forest of Quebec. For. Ecol. Manage. 92: 235-242.

Bergeron, Y., B. Harvey, A. Leduc and S. Gauthier. 1999. Forest management guidelines based on natural disturbance dynamics: stand- and forest-level considerations. For. Chron. 75: 49-54.

Bradshaw, R., P. Gemmel and L. Björkman. 1994. Development of nature-based silvicultural models in southern Sweden: the scientific background. For. and Landscape Res. 1: 95-110.

Burton, P.J., A.C. Balisky, L.P. Coward, S.G. Cumming and D.D. Kneeshaw. 1992. The value of managing for biodiversity. For. Chron. 68: 225-237.

Burton, P.J. and K.D. Coates. 1996. Characterizing old growth and strategies for old growth management in the Sub-Boreal Spruce Zone. Exten. Note 14, Prince Rupert For. Reg., For. Sci. Sect., B.C. Min. For., Smithers, B.C. 9 p.

Christensen, N.L, A.M. Bartuska, J.H. Brown, S. Carpenter, C. D'Antonio, R. Francis, J.F. Franklin, J.A. MacMahon, R.F. Noss, D.J. Parsons, C.H. Peterson, M.G. Turner and R.G. Woodmansee. 1996. The report of the Ecological Society of America committee on the scientific basis for ecosystem management. Ecol. Applic. 6: 665-691.

Clark, D.F. 1994. Post-fire succession in the Sub-Boreal Spruce forests of the Nechako Plateau, central British Columbia. M.Sc. Thesis, Univ. 
of Victoria, Victoria, B.C.

Coates, D. 1997. Logging options for the boreal forest that address ecosystem management objectives. In V. Loewen, S. Olsen, S. Francis, and M. Gill. (organizers). Ecosystem-based management: application to Yukon forests. Presentation of the Yukon Forest Strategy Conference on Ecosystem-based Management, Whitehorse, March 24-26, 1997. pp. 86-94.

Coates, K.D and P.J. Burton. 1997. A gap-based approach for development of silvicultural systems to address ecosystem management objectives. For. Ecol. Manage. 99: 337-354.

Coates, K.D. and J.D. Steventon. 1995. Patch retention harvesting as a technique for maintaining stand level biodiversity in forests of north central British Columbia. In C.R. Bamsey (ed.). Innovative Silviculture Systems in Boreal Forests. pp. 102-106. Clear Lake Ltd. Edmonton, Alberta.

Cumming, S.G., P.J. Burton and B. Klinkenberg. 1996. Boreal mixedwood forests may have no "representative" areas: some implications for reserve design. Ecography 19: 162-180.

Curtis, R.O. 1997. The role of extended rotations. In K.A. Kohm and J.F. Franklin (eds.). Creating a forestry for the $21^{\text {st }}$ century: the science of ecosystem management. pp. 165-170. Island Press, Covelo, California.

Curtis, R.O. and D.D. Marshall. 1993. Douglas-fir rotations: time for reappraisal? West. J. Appl. For. 8: 81-85.

DeLong, S.C. and D. Tanner. 1996. Managing the pattern of forest harvest: lessons from wildfire. Biodiv. and Conserv. 5: 1191-1205. Eberhart, K.E. and P.M. Woodward. 1987. Distribution of residual vegetation associated with large fires in Alberta. Can. J. For. Res. 17: $1207-1212$.

Franklin, J.F., K. Cromack, W. Denison, A. McKee, C. Maser, J. Sedell, F. Swanson, and G. Juday. 1981. Ecological characteristics of old-growth Douglas-fir forests. Gen. Tech. Rep. PNW118, USDA For. Serv. Portland, Oregon.

Franklin, J.F., D.R. Berg, D.A. Thornburgh and J.C. Tappeiner. 1997. Alternative silvicultural approaches to timber harvesting: variable retention harvest systems. In K.A. Kohm and J.F. Franklin (eds.). Creating a forestry for the $21^{\text {st }}$ century: the science of ecosystem management. pp. 111-139. Island Press, Covelo, California.

Fries, C., O. Johansson, B. Pettersson and P. Simonsson, P. 1997. Silvicultural models to maintain and restore natural stand structures in Swedish boreal forests. For. Ecol. Manage. 94: 89-103. Galindo-Leal, C. and F.L. Bunnell. 1995. Ecosystem management: implications and opportunities of a new paradigm. For. Chron. 71: 601-606.

Gauthier, S., A. Leduc and Y. Bergeron. 1996. Vegetation modelling under natural fire cycles: a tool to define natural mosaic diversity for forest management. Environ. Monit. Assess. 39: 417-434.

Goward, T. 1994. Notes on oldgrowth-dependent epiphytic macrolichens in inland British Columbia, Canada. Acta Bot. Fennica 150: 31-38.

Hagar, J.C., W.C. McComb and W.H. Emmingham. 1996. Bird communities in commercially thinned and unthinned Douglas-fir stands of western Oregon. Wild. Soc. Bull. 24: 353-366.

Hammond, H. 1991. Seeing the forest among the trees: the case for wholistic forest use. Polestar Press, Vancouver, B.C. 309 p.

Hansen, A.J, T.A. Spies, F.J. Swanson and J.L. Ohmann. 1991. Conserving biodiversity in managed forests: lessons from natural forests. BioScience 41: 382-392.

Harris, L.D. 1984. The fragmented forest. Univ. of Chicago Press, Chicago. 211 p.

Hayward, G.D. 1991. Using population biology to define oldgrowth forests. Wildl. Soc. Bull. 19: 111-116.

Heinselman, M.L. 1981. Fire and succession in the conifer forests of North America. In D.C. West, H.H. Shugart and D.B. Botkin (eds.). Forest succession: concepts and applications. pp. $374-405$. SpringerVerlag, New York.
Hunter, M.L. 1989. What constitutes an old-growth stand? J. For. 87: 33-35.

Hunter, M.L. 1990. Wildlife, forests, and forestry: principles of managing forests for biological diversity. Prentice-Hall, Englewood Cliffs, New Jersey. 370 p.

Hunter, M.L. 1993. Natural fire regimes as spatial models for managing boreal forests. Biol. Cons. 65: 115-120.

Johnson, E.A. 1992. Fire and vegetation dynamics: studies from the North American boreal forest. Cambridge University Press, Cambridge, U.K. 129 p.

Johnson, E.A., K. Miyanishi and J.M.H. Weir. 1995. Old-growth, disturbance, and ecosystem management. Can. J. Bot. 73: 918-926. Johnson, E.A. and C.E. Van Wagner. 1985. The theory and use of two fire history models. Can. J. For. Res. 15: 214-220.

Kaufmann, M.R., W.H. Moir and W.W. Covington. 1992. Oldgrowth forests: what do we know about their ecology and management in the Southwest and Rocky Mountain regions? In M.R. Kaufmann, W.H. Moir and R.L. Basett (tech. coords.). Old-growth forest in the Southwest and Rocky Mountain regions: proceedings of a workshop. pp. 1-11. Gen. Tech. Rep. RM-213. USDA For. Serv., Fort Collins, Colorado.

Keenan, R.J. and J.P. Kimmins. 1993. The ecological effects of clearcutting. Environ. Rev. 1: 121-144.

Kneeshaw, D.D. and P.J. Burton. 1997. Canopy and age structures of some old sub-boreal Picea stands in British Columbia. J. Veg. Sci. 8: 615-626.

Kneeshaw, D.D. and P.J. Burton. 1998. Assessment of functional old-growth status: a case study in the Sub-Boreal Spruce zone of British Columbia, Canada. Nat. Areas J. 18:293-308.

Larsen, J.A. 1980. The boreal ecosystem. Academic Press, Toronto, Ontario. 500 p.

Lertzman, K., T. Spies and F. Swanson. 1997. From ecosystem dynamics to ecosystem management. In P.K. Schoonmaker, B. von Hagen and E.C. Wolf (eds.). The rain forests of home: profile of a North American bioregion. pp. 361-382. Island Press, Covelo, California.

Lieffers, V.J., R.B. Macmillan, D. MacPherson, K. Branter and J.D. Stewart. 1996. Semi-natural and intensive silvicultural systems for the boreal mixedwood forest. For. Chron. 72: 286-292.

McComb, W.C., T.A. Spies and W.H. Emmingham. 1993. Douglas-fir forests: managing for timber and mature-forest habitat. J. For. 91: $31-42$.

Mehl, M.S. 1992. Old-growth descriptions for the major forest cover types in the Rocky Mountain Region. In M.R. Kaufmann, W.H. Moir and R.L. Basett (tech. coords.). Old-growth forest in the Southwest and Rocky Mountain regions: proceedings of a workshop. pp. 106-120. Gen. Tech. Rep. RM-213. USDA For. Serv., Fort Collins, Colorado.

Meidinger, D., J. Pojar and W.L. Harper. 1991. Sub-boreal spruce zone. In D. Meidinger and J. Pojar (eds.). Ecosystems of British Columbia. pp. 209-221. Spec. Rep. Ser. 6., B.C. Min. For., Victoria, B.C.

Moir, W.H. 1992. Ecological concepts in old-growth forest definition. In M.R. Kaufmann, W.H. Moir and R.L. Basett (tech. coords.). Old-growth forest in the Southwest and Rocky Mountain regions: proceedings of a workshop. pp. 18-23. Gen. Tech. Rep. RM-213. USDA For. Serv., Fort Collins, Colorado.

Newton, M. and E.C. Cole. 1987. A sustained yield scheme for oldgrowth Douglas-fir. West. J. Appl. For. 2: 22-25.

Oliver, C.D. and B.C. Larson. 1990. Forest stand dynamics. McGraw Hill, Toronto, Ontario. 467 p.

Payette, S. 1992. Fire as a controlling process in the North American boreal forest. In H.H. Shugart, R. Leemans and G.B. Bonan (eds.), A systems analysis of the global boreal forest. pp. 144-169. Cambridge University Press, Cambridge, U.K.

Perry, D.A. 1994. Ecosystem silviculture: ecological principles, implications for communities. Can. Silv. Mag. 2(1): 6-12.

Pojar, J., E. Hamilton, D. Meidinger and A. Nicholson. 1992. Old 
growth forests and biological diversity in British Columbia. In G.B. Ingram and M.R. Moss (eds.). Landscape approaches to wildlife and ecosystem management. pp. 85-97. Polyscience Publications, Morin Heights, Ontario.

Robinson, G. 1988. The forest and the trees: a guide to excellent forestry. Island Press, Covelo, California. 257 p.

Rolston, H. 1979. Can and ought we to follow nature? Environ. Ethics 1: 7-30.

Rülcker, C., P. Angelstam and P. Rosenberg. 1994. Natural forest-fire dynamics can guide conservation and silviculture in boreal forests. Skog Forsk Results No. 2., Uppsala, Sweden. 4 p.

Runkle, J.R. 1991. Gap dynamics of old-growth eastern forests: management implications. Nat. Areas J. 11: 19-25.

Singer, M.T. and C.G. Lorimer. 1997. Crown release as a potential old-growth restoration approach in northern hardwoods. Can. J. For. Res. 27: 1222-1232.

Swanson, F.J. and J.F. Franklin. 1992. New forestry principles from ecosystem analysis of Pacific Northwest forests. Ecol. Applic. 2: 262-274. Teeguarden, D.E. 1982. Managing timber resources. In W.A. Duerr, D.E. Teeguarden, N.B. Christiansen and S. Guttenberg. (eds.). Forest resource management: decision-making principles and cases, revised edition. pp. 173-198. O.S.U. Book Stores, Corvallis, Oregon.
Thomas, J.W., L.F. Ruggiero, R.W. Mannan, J.W. Schoen and R.A. Lancia. 1988. Management and conservation of old-growth in the U.S. Wildl. Soc. Bull. 16: 252-261.

Vora, R.S. 1994. Integrating old-growth forest into managed landscapes: a Northern Great Lakes perspective. Nat. Areas J. 14: 113-123.

Wells, R.W., K.P. Lertzman and S.C. Saunders. 1998. Oldgrowth definitions for the forests of British Columbia, Canada. Nat. Areas J. 18: 279-292.

Whitney, G.G. 1987. Some reflections on the values of old-growth forests, scientific and otherwise. Nat. Areas J. 7: 92-99.

Zasada, J.C., T.L. Sharik and M. Nygren. 1992. The reproductive process in boreal forest trees. In H.H. Shugart, R. Leemans and G.B. Bonan (eds.). A systems analysis of the global boreal forest. pp. 85-125. Cambridge University Press, Cambridge, U.K. 